\title{
Coral-algal interactions at Weizhou Island in the northern South China Sea: variations by taxa and the exacerbating impact of sediments trapped in turf algae
}

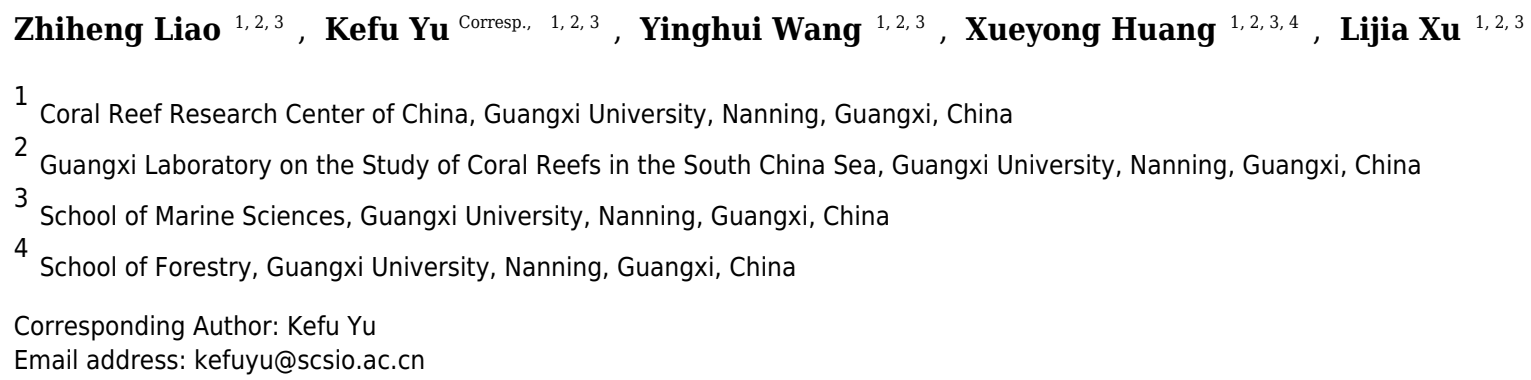

Competitive interactions between corals and benthic algae are increasingly frequent on degrading coral reefs, but the processes and mechanisms surrounding the interactions, as well as the exacerbating effects of sediments trapped in turf algae, are poorly described. We surveyed the frequency, proportion, and outcomes of interactions between benthic algae (turf algae and macroalgae) and 631 corals (genera: Porites, Favites, Favia, Platygyra, and Pavona) on a degenerating reef in the northern South China Sea, with a specific focus on the negative effects of algal contact on corals. Our data indicated that turf algae were the main algal competitors for each surveyed coral genus and the proportion of algal contact along the coral edges varied significantly among the coral genera and the algal types. The proportions of algal wins between corals and turf algae or macroalgae differed significantly among coral genera. Compared to macroalgae, turf algae consistently yielded more algal wins and fewer coral wins on all coral genera. Amongst the coral genera, Porites was the most easily damaged by algal competition. The proportions of turf algal wins on the coral genera increased 1.1-1.9 times in the presence of sediments. Furthermore, the proportions of algal wins on massive and encrusting corals significantly increased with the combination of sediments and turf algae as the algal type. However, the variation in proportions of algal wins between massive and encrusting corals disappeared as sediments became trapped in turf algae. Sediments bound within turf algae further induced damage to corals and reduced the competitive advantage of the different coral growth forms in their competitive interactions with adjacent turf algae. 
1 Coral-algal interactions at Weizhou Island in the northern South

2 China Sea: variations by taxa and the exacerbating impact of

3 sediments trapped in turf algae

4 Zhiheng Liao ${ }^{1-3}$, Kefu $\mathrm{Yu}^{1-3}$, Yinghui Wang ${ }^{1-3}$, Xueyong Huang ${ }^{1-4}, \mathrm{Lijia}^{\mathrm{Xu}} \mathrm{u}^{1-3}$

51 Coral Reef Research Center of China, Guangxi University, Nanning, Guangxi, China

62 Guangxi Laboratory on the Study of Coral Reefs in the South China Sea, Guangxi University,

$7 \quad$ Nanning, Guangxi, China

83 School of Marine Sciences, Guangxi University, Nanning, Guangxi, China

94 School of Forestry, Guangxi University, Nanning, Guangxi, China

10 Corresponding authors:

11 Kefu $\mathrm{Yu}^{1-3}$

12 Email address: kefuyu@scsio.ac.cn 
13 Abstract

14 Background. Competitive interactions between corals and benthic algae are increasingly

15 frequent on degrading coral reefs, but the processes and mechanisms surrounding the interactions, 16 as well as the exacerbating effects of sediments trapped in turf algae, are poorly described.

17 Methods. We surveyed the frequency, proportion, and outcomes of interactions between benthic 18 algae (turf algae and macroalgae) and 631 corals (genera: Porites, Favites, Favia, Platygyra, and Pavona) on a degenerating reef in the northern South China Sea, with a specific focus on the negative effects of algal contact on corals.

Results. Our data indicated that turf algae were the main algal competitors for each surveyed coral genus and the proportion of algal contact along the coral edges varied significantly among the coral genera and the algal types. The proportions of algal wins between corals and turf algae or macroalgae differed significantly among coral genera. Compared to macroalgae, turf algae consistently yielded more algal wins and fewer coral wins on all coral genera. Amongst the coral genera, Porites was the most easily damaged by algal competition. The proportions of turf algal wins on the coral genera increased 1.1-1.9 times in the presence of sediments. Furthermore, the proportions of algal wins on massive and encrusting corals significantly increased with the combination of sediments and turf algae as the algal type. However, the variation in proportions of algal wins between massive and encrusting corals disappeared as sediments became trapped in turf algae. 
32 Discussion. Sediments bound within turf algae further induced damage to corals and reduced the 33 competitive advantage of the different coral growth forms in their competitive interactions with 34 adjacent turf algae. 


\section{Introduction}

36 Coral reefs around the world, including those of the South China Sea, have been undergoing

37 rapid degradation due to anthropogenic stressors and changes in their natural environment $(\mathrm{Yu}$,

38 2012). Macroalgae and turf algae generally tend to increase in abundance in degraded reefs

39 (Nugues and Bak, 2006; Haas et al., 2010) and develop intense competitive interactions with the

40 remaining corals (Hughes, 1994; McCook et al., 2001; Bellwood et al., 2004). This is

41 particularly pronounced in reefs that experience frequent human activity (Barott et al., 2012;

42 Brown et al., 2017). Indeed, phase shifts from coral to algal domination in reefs have been

43 observed with increasing frequency as a result of overfishing (Hughes, 1994), eutrophication

44 (Littler et al., 2006), sediment deposition (Goatley and Bellwood, 2013; Goatley et al., 2016),

45 and global climate change (Hoegh-Guldberg et al., 2007).

The interaction between benthic algae and scleractinian corals can be a major determinant

47 of reef community structure and composition, particularly in degrading reefs that are dominated by macroalgae (McCook et al., 2001). The outcomes of such interactions mainly depend on the species involved (McCook et al., 2001; Nugues and Bak, 2006), as the competitive mechanisms and strengths of algae and the resistance abilities of corals varies among species (Jompa and

51 McCook, 2003; Nugues and Bak, 2006; Bonaldo and Hay, 2014). Moreover, polyp size

52 (hypothesized by McCook et al., 2001), coral colony size (Barott et al., 2012; Ferrari et al., 2012;

53 Brown et al., 2017), coral growth form (Swierts and Vermeij, 2016), and environmental factors

54 (Vermeij et al., 2010) are also important determinants of the outcomes of coral-algal 
competitions. Barott et al. (2012) found that large and small coral colonies were more successful in competing against algae than mid-sized corals because they were able to allocate more energy to the competition. Different coral growth forms can also influence the nature of competitive interactions between coral and algae (Swierts and Vermeij, 2016). Different growth forms use either one of two, or both, strategies to compete against algae: the 'escape in height' strategy, in which corals invest energy in vertical growth to escape algal competition, and the 'direct confrontation' strategy, in which corals directly fight off algal invasion (Meesters and Wesseling et al., 1996; McCook et al., 2001; Swierts and Vermeij, 2016). In addition to these strategies, McCook et al. (2001) suggested that coral species-specificity can affect the outcomes of their interactions with algae. This interactive process depends more on the properties (e.g., species, functional groups, etc.) of the algae than of the coral (McCook et al., 2001; Jompa and McCook, 2003).

On coral reefs, macroalgae and turf algae are the main competitors against corals for space (McCook et al., 2001; Vermeij et al., 2010). With regard to coral-algal interactions, macroalgae are the most frequently researched and have been shown to inhibit nearby coral growth (Jompa and McCook, 2003; Titlyanov et al., 2007), recruitment (Birrell et al., 2008; Vermeij et al., 2009) and fecundity (Foster et al., 2008). Crustose coralline algae (CCA) are generally thought to have positive or minimal negative effects on corals (Negri et al., 2001; Harrington et al., 2008;

Vermeij and Sandin, 2008). Compared to macroalgae and CCA, turf algae grow quickly and can pre-emptively colonize available space (McCook et al., 2001; Littler et al., 2006). Turf algae 
75

76

77

interact most frequently with corals on degraded reefs (Littler et al., 2006; Haas et al., 2010) and can cause hypoxia (Smith et al., 2006; Wangpraseurt et al., 2012; Gregg et al., 2013; Haas et al., 2013; Roach et al., 2017), physical damage (McCook et al., 2001), bleaching (Titlyanov, et al., 2007; Rasher and Hay, 2010; Rasher et al., 2011), and disease (Barott and Rohwer, 2012) in adjacent corals. Turf algae have also been seen to have critical negative effects on the settlement and recruitment of coral larvae (Birrell et al., 2005; Birrell et al., 2008). In addition, algal turfs often accumulate a variety of sediments on the reef substrate (Purcell, 2000; Birrell et al., 2005), which exacerbate the stress and mortality that they cause in underlying corals and CCA (Steneck, 1997; Nugues and Roberts, 2003; Cetz-Navarro et al., 2013). The harmful effects of sediments are influenced by water flow, e.g., low flow rates can increase the rates of sediment accumulation (Gowan et al., 2014). When sediments are bound within turf algae, grazing by herbivores may also be inhibited (Wilson and Bellwood, 1997; Bellwood and Fulton, 2008; Goatley and Bellwood, 2011), which further enables the growth of algal turfs and hinders the settlement of coral larvae (Birrell et al., 2005; Goatley et al., 2016).

Although various researchers have conducted sound investigations into the influences of different algae on corals, their field surveys often do not consider the diversity of traits associated with the competitors or the environmental factors that could influence the outcome of coral-algal interactions. Field surveys on the influence of coral traits (e.g., genus, growth form, polyp size, etc.) and sediments on coral-algal interactions may help to improve our understanding of the complex processes involved in these competitive interactions. Such insights 
95

96

97

98

99

100

101

102

103

104

105

106

107

108

109

110

111

112

113

may be helpful in the selection of corals for use as coral transplants in the restoration of degraded coral reefs that have become dominated by algae.

and macroalgae (Lobophora variegata and Bryopsis pennata) on five common coral genera

(Pavona, Porites, Favites, Favia, and Platygyra) on the coral reef of Weizhou Island, northern

South China Sea. The study objectives were: (1) to survey the frequency of coral-algal contact, as well as the composition and proportion of contiguous algae along the coral edges; (2) to determine the outcomes of the competitive interactions between the common corals and dominant algae; and (3) to determine the impact of accumulated sediments on the negative effects of turf algae (i.e., algal wins) on corals. Our central hypothesis was that sediment deposition would increase the competitiveness of turf algae in coral-algal interactions, enable them to overgrow corals, and reduce the competitive advantage of the coral growth forms.

\section{Materials and methods}

\section{Study site}

The survey was conducted in October 2015 (autumn) at Weizhou Island $\left(21^{\circ} 03^{\prime} \mathrm{N}, 109^{\circ} 07^{\prime} \mathrm{E}\right)$;

the largest and youngest volcanic island in the Chinese coastal areas, located $48 \mathrm{~km}$ from the mainland coastline in the Beibu Gulf in the northern South China Sea (Fig. 1A). Weizhou Island has experienced a dramatic decline in its coral reefs since the 1990s: from $80 \%$ coral cover to an estimated current live coral cover of less than $10 \%$ (Wang et al., 2016). The rapid development 
114 of tourism, fishing, aquaculture, and other human activities in recent years have likely had

115 detrimental effects on the coral reef ecosystem. In addition, long-term investigations have

116 indicated that fish populations have been at low levels for a long time (Chen et al., 2015).

117 However, no recent surveys have been conducted on the benthic algae of the Weizhou coral reef.

\section{Benthic cover}

119 Field research was conducted with permission from the School of Marine Sciences, Guangxi

120 University. Coverage of hard corals and benthic algae and coral-algal interactions were surveyed

121 along transects at four sites on the reef flat of Weizhou Island. The distance between sites was

122 greater than $1 \mathrm{~km}$ (Fig. 1B). Two $100 \mathrm{~m}$ parallel transects, separated by over $100 \mathrm{~m}$, were

123 installed at each of the four sites at a depth of 3-7 m; i.e., a total of eight transects were surveyed.

124 For each transect, a $100 \mathrm{~m}$ fiberglass measuring tape was fixed to the reef flat and sampling

125 quadrats $(0.5 \times 0.5 \mathrm{~m})$ were placed every $10 \mathrm{~m}$ along the transect.

An OLYMPUS TG-4 camera (effective pixel density: 12 million pixels) was used to

photograph each quadrat. Benthic cover and composition were analyzed using Coral Point Count with Excel extensions (CPCe) software that used 50 randomly-placed points within each frame

(Preskitt et al., 2004; Kohler and Gill, 2006). Reef benthic cover was calculated from 11 quadrats along each of the 8 transects, i.e., $\mathrm{n}=88$ quadrats. Hard corals were identified to the genus level, macroalgae were identified to the species or genus level, and CCA and turf algae were classified as individual functional groups. We also identified other benthic organisms, such as soft corals and sponges. Non-biological substrates were classified as sand, rock, rubble, and dead coral. 


\section{Frequency of contact, proportion, and outcomes of coral-algal interactions}

135

Videos were also recorded along each transect (as previously described) using an OLYMPUS TG-4 camera, held 15-25 $\mathrm{cm}$ above the benthos by a SCUBA diver at a swimming speed of $4 \mathrm{~m}$ $\min ^{-1}$. The frequency and proportion of coral-algal interactions (i.e., algal contacts along coral edges) were assessed based on screenshots of the transect videos. We derived top-view photographs (screenshots) of the common corals (Porites, Favites, Favia, Platygyra, and Pavona genera). We ensured that these photographs clearly reflected information regarding the coral genus, algal type, and algal contacts along the coral edge (Fig. 2), and that the coral colony photographs revealed over half of the coral edge. We also ensured that part of the tape measure was visible alongside or above the measured corals in these photographs for the accurate quantification of coral edge perimeters and identification of the outcomes of coral-algal interactions (Fig. 2E). Using these photographs, we carefully investigated and recorded features of the coral colonies, i.e., coral genus, growth form, and perimeter; we visually examined the edges of the corals for the presence or absence of turf algae and macroalgae; and we quantified the proportion of coral-algal interactions. CCA were ignored as they had minimal interactions with the corals. Using the software ImageJ 1.50i (Abramoff et al., 2004), we determined the type and proportion of coral-algal interactions, and we recorded the contact length of each species and functional group of algae at each coral edge (Fig. 2E). The percentage of contact of each algal species around the coral was calculated by dividing the contact length of each algal taxon by the total perimeter of the coral. The outcomes of coral-algal interactions were visually evaluated 
154 from the interface (e.g., Figs. 2A and 2B) and classified as coral win, algal win, or neutral

155 outcome. An outcome was scored as 'coral win' if the coral had grown taller than the contiguous

156 algae or had damaged the adjoining algal tissue. An outcome was scored as 'algal win' if the

157 coral edge showed signs of tissue necrosis, discoloration, bleaching, or if the algae had

158 overgrown the coral colony (Barott et al., 2012; Swierts and Vermeij, 2016). An outcome was

159 scored as 'neutral' if neither the coral nor the algae caused damage or overgrowth at their interaction interface (see Barott et al., 2012, Fig. 2). The proportions of algal wins were calculated for each coral by dividing the length of damage from the algae by the total length of contact of each type of algae along the coral edge. The proportions of coral wins and neutral outcomes were calculated using the same equation with respective substitutes. Outcomes were grouped by coral genera and colony growth forms, i.e., coral colonies were classified as one of three growth forms: encrusting (colonies encrusting the substrate without upward growth), massive (solid colonies with similar size in all directions), and upright (colonies growing upward with a small base fixed to the substrate) based on the growth morphology of the dominant surveyed coral genera. Some coral genera, including Porites, Favites, Favia, and Platygyra, were found in both encrusting and massive growth forms, while the Pavona genus was found only in the upright growth form. The polyp sizes of each coral genera were classified as being smaller

171 than $2 \mathrm{~mm}$ (i.e., Porites and Pavona genera) or larger than $5 \mathrm{~mm}$ (i.e., Favites, Favia, and 172 Platygyra genera). 


\section{Determining the effects of accumulated sediments}

174 Even a small amount of turf algae can collect a large quantity of sediment on near-shore reef

175 substrata (Figs. 2C and 2D). Sediments were identified using magnified (1-2 times) photographs.

176 Gray sediments sharply contrasted the colors (red, green, and brown) of the turf algae, and their

177 presence or absence in the turf algae was recorded non-quantitatively. Turf algae that interacted

178 with corals were divided into two categories, namely 'turf algae with sediment' (Turf + S) and

179 'turf algae without sediment' (Turf $-\mathrm{S}$ ). We compared the proportions of algal wins that resulted

180 from encounters between the coral colonies and 'Turf $+\mathrm{S}$ ', and between coral colonies and 'Turf $181-\mathrm{S}^{\prime}$

\section{Statistical analyses}

183 Homogeneity of variances was tested on all data using Levene's test. Parametric and non-

184 parametric analyses were applied to data that were homoscedastic and non-homoscedastic,

185 respectively. The proportions of algal contacts (i.e., coral-algal interactions) were analyzed for

186 differences between coral genera and algal types (e.g., macroalgae, 'Turf + S', and 'Turf - S')

187 using a two-way ANOVA, with the coral genus and algal type as fixed factors. Differences in the

188 proportions of a specific competitive outcome (e.g., coral win, algae win, or neutral) among coral

189 genera were quantified using a Kruskal-Wallis test followed by a Student-Newman-Keuls (SNK)

190 post-hoc comparison. To assess the differences in the proportions of algal wins, a two-way

191 ANOVA was used (with the type of turf algae or macroalgae genus and coral genus as fixed

192 factors), followed by an SNK test. To assess the differences in the proportions of algal wins and 
193 the similarity among interaction groups (including: massive corals vs. 'Turf $-\mathrm{S}$ ', massive corals

194 vs. 'Turf + S', encrusting corals vs. 'Turf - S', and encrusting corals vs. 'Turf + S'), a two-way

195 ANOVA (with the type of turf algae and coral growth form as fixed factors) was used, followed

196

197

198

199

200

201

202

203

204

205

206

207

208

209

210

211

by an SNK test. All statistical analyses were conducted using IBM SPSS Statistics 19 software and $p<0.05$ were considered statistically significant.

\section{Results}

\section{Benthic cover}

The benthos of Weizhou Island consisted of $7 \%$ hard coral, $31 \%$ benthic algae, $5 \%$ other biological substrates, and the residual $57 \%$ consisted of non-biological substrates (Fig. 1B). The five common coral genera, Pavona, Porites, Favites, Favia, and Platygyra accounted for $31 \%$, $23 \%, 13 \%, 11 \%$, and $4 \%$ of the total hard coral cover, respectively (Fig. 3A). The major algal functional group was turf algae, which made up $23 \%$ of the total benthic cover. Macroalgae contributed relatively little to the benthic coverage, at $4 \%$ L. variegata and $2 \% \mathrm{~B}$. pennata. Other algae contributed $\sim 2 \%$ to the total benthic coverage (Fig. 3B).

\section{Algal composition, contact frequency, and proportion around the coral edges}

In total, 631 coral colonies with a combined perimeter of $25,716 \mathrm{~cm}$ were measured in the surveyed transects. Amongst all genera, Porites was the most frequently in contact with algae $(86 \pm 2.4 \%$ of colonies; mean $\pm \mathrm{SE})$, followed by Favia $(85 \pm 2.7 \%)$ and Favites $(80 \pm 5.5 \%$;

Table 1). The proportions of algal contacts varied significantly with coral genera and with algal 
212 types, and a significant interaction was found between coral genus and algal type (two-way

213 ANOVA, coral genera: $F=11.99, \mathrm{df}=4,1889, p<0.0001$; algal types: $F=55.22, \mathrm{df}=2,1889$,

$214 p<0.0001$; interaction: $F=11.36, \mathrm{df}=8,1889, p<0.0001$; Table 2 ). The mean percentage of

215 coral edges in contact with algae was higher for turf algae $(38 \pm 1.0 \%$, which consisted of $19 \pm$

$2160.9 \%$ 'Turf $-\mathrm{S}$ ' and $19 \pm 1.0 \%$ 'Turf $+\mathrm{S}$ ') than for macroalgae $(6 \pm 0.5 \%, \mathrm{n}=631$; Table 1$)$.

217 The Porites genus was the most frequently engaged in algal contact $(\mathrm{n}=211,53 \pm 1.9 \%)$, while

218 the Pavona genus was the least frequently engaged in algal contact $(\mathrm{n}=113,27 \pm 2.2 \%$; Table

$2191)$.

\section{Interactions between corals and algae}

221 The proportions of algal wins between the corals and turf algae were significantly higher in

222 interactions with the Porites genus (which have a small polyp size), i.e., $76 \pm 1.7 \%(\mathrm{mean} \pm \mathrm{SE})$

223 of the interaction outcomes (65\% algal overgrowth and $11 \%$ coral bleaching), than with any

224 other coral genera with large polyp sizes (Kruskal-Wallis, $\mathrm{X}^{2}=147.65, \mathrm{df}=4, p<0.0001$; Fig.

225 4B). Proportions of turf algal wins in interactions with Platygyra, Favites, and Favia genera

226 (which have large polyp sizes) ranged from $40 \pm 5.7 \%$ to $51 \pm 3.1 \%$ but did not significantly

227 differ among these genera (Fig. 4B). In these genera, algal overgrowth was the major contributor

228 to algal wins, with few instances of coral bleaching occurring. Proportions of neutral outcomes

229 differed significantly among coral genera, with this outcome being significantly less occurred in

230 the Porites genus than in any other coral genera (Kruskal-Wallis, $\mathrm{X}^{2}=68.27, \mathrm{df}=4, p<0.0001$;

231 Fig. 4B). There were significant differences in the proportions of coral wins in coral-turf algal 
232

233 Corals with small polyp sizes $(<2 \mathrm{~mm})$, such as the Porites and Pavona genera, were least

234 successful in turf algal interactions and accounted for $4 \pm 1.0 \%$ and $7 \pm 2.8 \%$ of the coral wins, 235 respectively (Fig. 4B).

236

$237=22.93, \mathrm{df}=4, p=0.0001$; Fig. 5B). Of the five coral genera, Porites was the most susceptible

238

239

240

241

242

243

244

245

246

247

248

249

250

251

interactions among the coral genera (Kruskal-Wallis, $\mathrm{X}^{2}=15.43 \mathrm{df}=4, p=0.0039$; Fig. 4B).

Proportions of macroalgal wins varied significantly among coral genera (Kruskal-Wallis, $\mathrm{X}^{2}$ to damage by macroalgae, with macroalgal wins accounting for $64 \pm 5.5 \%$ (mean $\pm \mathrm{SE}$ ) of their interaction outcomes (Fig. 5B). The proportions of macroalgal wins in the Favia, Pavona, Platygyra, and Favites genera ranged from $22 \pm 4.0 \%$ to $51 \pm 10.4 \%$ (Fig. 5B). The proportions of neutral outcomes in coral-macroalgal interactions did not significantly differ among coral genera (Kruskal-Wallis, $\mathrm{X}^{2}=6.80, \mathrm{df}=4, p=0.147$; Fig. 5B). Corals were more successful in outcompeting macroalgae, with proportions of coral wins ranging from $9 \pm 3.5 \%$ to $55 \pm 6.4 \%$ (Kruskal-Wallis, $\mathrm{X}^{2}=37.65, \mathrm{df}=4, p<0.0001$; Fig. 5B).

\section{Negative effects of macroalgae and turf algae in contact with corals}

Proportions of turf algal wins varied among the types of turf algae and the coral genera, but there were no interactions between the type of turf algae and coral genus (two-way ANOVA, types of turf algae: $F=30.15, \mathrm{df}=1,655, p<0.0001$; coral genera: $F=57.70, \mathrm{df}=4,655, p<0.0001$; interaction: $F=1.57, \mathrm{df}=4,655, p=0.1810$; Fig. $6 \mathrm{~A})$. The Porites genus showed significantly higher proportions of turf algal wins than other coral genera, regardless of whether the turf algae contained sediments (Fig. 6A). In all coral genera, proportions of algal wins in 'Turf $+\mathrm{S}$ ' 
252

253

254

255

256

257 258

competitions were 1.1 to 1.9 times higher than in 'Turf $-\mathrm{S}$ ' competitions (Fig. 6A).

In contrast, macroalgae had fewer proportions of algal wins than turf algae. Similar to turf algae, their proportions of algal wins varied with macroalgae and coral taxa, but no interactions were found between macroalgal species and coral genus (two-way ANOVA, macroalgae genera: $F=40.48, \mathrm{df}=1,181, p<0.0001 ;$ coral genera: $F=9.35, \mathrm{df}=4,181, p<0.0001$; interaction: $F$ $=1.14, \mathrm{df}=4,181, p=0.3399$; Fig. 6B). Within the coral genera, algal wins of brown algae $L$. variegata were 2.5 to 5.7 times more frequent than those of green algae B. pennata. Both species caused the most harm to the Porites genus $(93 \pm 2.4 \%$ for L. variegata and $37 \pm 7.6 \%$ for B. pennata; mean \pm SE; Fig. 6B).

\section{Negative effects of turf algae on massive and encrusting corals}

The effects of the coral growth form and the sediment on the outcomes of coral and turf algae interactions were analyzed for the Porites, Favites, Favia, and Platygyra genera. The proportions of algal wins varied significantly between the two types of turf algae, but did not vary significantly between the two coral growth forms (massive and encrusting), and a significant interaction was found between the types of turf algae and coral growth forms (two-way ANOVA, types of turf algae: $F=28.42, \mathrm{df}=1,585, p<0.0001$; coral growth forms: $F=1.26, \mathrm{df}=1,585$, $p=0.2625$; interaction: $F=4.23, \mathrm{df}=1,585, p=0.0401$; Fig. 7). For the same coral growth forms, the proportions of turf algal wins increased significantly when sediments were trapped in the turf algae (Fig. 7). The proportions of algal wins of 'Turf - S' were significantly higher on massive corals than on encrusting corals (Fig. 7). However, the proportions of algal wins caused 
272 by 'Turf $+\mathrm{S}$ ' did not differ significantly between these two coral growth forms (Fig. 7).

\section{Discussion}

\section{Coral-algal interactions varied with algal taxa}

275 The majority of coral colonies competed with benthic algae, with interaction outcomes mostly

276 being in favor of the algae rather than the corals. The interactions of the algae and corals varied

277 among species and algal functional groups. Interactions between turf algae and corals were most

278 frequent, with the proportions of algal wins and the proportion of algal contacts being

279 considerably greater in turf algae than macroalgae (Table 1, Figs. 4 and 5). These findings have

280 previously been observed on degraded coral reefs, where contact with turf algae resulted in algal

281 overgrowth and caused bleaching or damage to adjacent corals (Haas et al., 2010; Wild et al.,

282 2014; Swierts and Vermeij, 2016). Some of our study findings were consistent with the results of

283 these previous studies, i.e., corals were frequently observed to suffer overgrowth by turf algae;

284 however, in the present study, coral bleaching was rarely observed. Although the causes of the

285 observed algal overgrowth and coral bleaching were not surveyed in this study, previous studies

286 have confirmed that turf algae can negatively influence corals by hypoxia and microbial growth

287 (Smith et al., 2006; Wangpraseurt et al., 2012; Gregg et al., 2013; Haas et al., 2013; Roach et al.,

288 2017). Turf algae may also influence corals via potential algal allelopathy (Jompa and McCook,

289 2003). Moreover, turf algae can rapidly increase in length and occur in both creeping and upright

290 growth forms (Hay, 1981; Connell et al., 2014), which allow it to rapidly and densely overgrow

291 adjacent corals. 
Because of its creeping growth pattern and thallus which can attach tightly to the coral surface, it is possible for L. variegata to smother and overgrow the subsurface of coral tissue (McCook et al., 2001; Nugues and Bak, 2006; Longo and Hay, 2015). Meanwhile, bleaching on neighboring corals may be associated with allelopathic or microbial mechanisms during the overgrowth of Lobophora spp.(Rasher and Hay, 2010; Vieira et al., 2016). In contrast, B. pennata is characterized by a prostrate rhizoid and erect pinnule, which possibly account for its lower frequency of damage to corals in this study. The soft and short erect pinnules of $B$. pennata may the Bryopsidales tend to bury their rhizoids in sand and sediment substrates for nutrient absorption (Williams, 1984; Friedlander et al., 2006), suggesting that hard coral may not be a suitable substrate for the growth of rhizophytic algae. Other investigators have reported that competition with Bryopsis sp. resulted in coral bleaching or tissue necrosis (Barott et al., 2009), but this was not recorded in our study. The effects of macroalgae on corals have been demonstrated, with a high variance in the potency of different algae and in the susceptibility of different corals (Rasher and Hay, 2010; Rasher et al., 2011). The interactions between macroalgae and corals varied among the different algal species, and these differences may be explained by algal growth patterns. 
312 Resistance to algal contact: driven by coral traits and growth forms

313 In our study, the proportions of algal wins of different algal interactions varied among coral

314 genera (Fig. 6). We found that the Porites genus was more susceptible to damage by algal

315 contact. Other studies have also demonstrated the sensitivity of Porites spp. to algal contact and

316 showed that they often suffered algal overgrowth, tissue bleaching, or even mortality (Titlyanov

317 et al., 2007; Rasher and Hay, 2010). The harmful influences of a specific macroalgae on corals

318 may be associated with specific coral traits, including taxonomy, growth form, and colony and

319 polyp size. McCook et al. (2001) hypothesized that size classes of the coral colonies and polyps

320 may be associated with the ability of corals to compete against algae. It seems that corals with

321 large polyps possess a higher tissue expansion potential than those with small polyps

322 (Erftemeijer et al., 2012), which enables them to perform better in resisting foreign matter

323 invasion (e.g., algae, and sediments). This phenomenon may account for our observation of the

324 Porites genus suffering greater damage from algal turf contact than the Favites, Favia, and

325 Platygyra genera, all of which have larger polyp sizes.

326 Meanwhile, the coral growth form has also been found to be an important determinant of

327 the outcomes of interactions between corals and turf algae (Lirman, 2001; Haas et al., 2010;

328 Swierts and Vermeij, 2016). Previous research found that encrusting corals suffered the least

329 harm from turf algae and that they had a higher percent of wins against turf algae than other coral

330 growth forms (Swierts and Vermeij, 2016). The combination of sediments on turf algae appears

331 to potentially alter the ability of the turf algae to damage different growth forms of coral (Fig. 7). 
332 The explanation for this may be that the combination of turf algae and sediments often

333 exacerbates their damaging effects on adjacent corals (Steneck, 1997; Erftemeijer et al., 2012;

334 Goatley and Bellwood, 2013). The proportions of algal wins of these combinations on massive

335 and encrusting corals were extremely similar. In such cases, the morphology of colonies did not

336 affect the coral-turf algal interactions. Thus, we hypothesized that the competitive advantage of

337 the encrusting coral disappeared in the interactions between coral and turf algae when turf algae

338 were combined with sediments.

\section{Sediments bound within turf algae can further affect the reef ecosystem}

340 Our results suggested that the proportions of turf algal wins were augmented when sediments

341 were trapped by turf algae (Figs. 6A and 7). Inshore coral reefs are usually exposed to high

342 levels of suspended sediments (Gilmour, 1999), and turf algae can trap considerable quantities of

343 sediments and reduce sediment resuspension (Purcell, 2000; Gowan et al., 2014). Water flow is

344 the key driver of sediments that influence the interactions between corals and turf algae (Gowan

345 et al., 2014). The water flow rate at Weizhou Island reef is low, with a seasonal range of 2.7-6.2

$346 \mathrm{~cm} \mathrm{~s}^{-1}$ (Wei et al., 2017). High sedimentation rates have also been recorded on the reef flat of

347 Weizhou Island, with an average deposition rate of $2157.9 \mathrm{~g} \mathrm{~m}^{-2} \mathrm{~d}^{-1}$ (Wang, 2009).

In addition, sediments in reefs contain an abundance of organic matter, and turf algae and

349 sediment combinations have been shown to promote the growth of turf algae and inhibit grazing

350 by herbivores (Wilson and Bellwood, 1997; Bellwood and Fulton, 2008; Goatley and Bellwood,

351 2011; Goatley et al., 2016). Herbivorous fish are a critical factor in coral reef environments, 
352 where grazing controls the abundance of benthic algae and coral-algal interactions (Rasher and

353 Hay, 2010; Bonaldo and Hay, 2014; Wild et al., 2014). The Reef Check on Weizhou Island reef

354 showed that the average density of reef fish was only 0.03 ind $\mathrm{m}^{-2}$ in the past few years (Chen et

355 al., 2016), which is lower compared to that of the Luhuitou fringing reef $\left(0.51 \mathrm{ind} \mathrm{m}^{-2}\right) 300 \mathrm{~km}$

356 from Weizhou Island (Sun et al., 2018). Thus, we speculated that the high frequency of coral-

357 algal interactions and negative effects of turf algae on corals may be attributed to the increase in

358 sediments trapped in the turf algae and the decrease in the abundance of herbivorous fish.

\section{Conclusions}

360 The present study aimed to demonstrate the influence of species-specificity and sediment 361 deposition on the outcomes of coral-algal interactions. We found that the outcomes of their 362 interactions were related to biotic (i.e., taxa and growth patterns of algae, genus, polyp size, and coral growth forms) and abiotic factors (i.e., sediments). In the competition between corals and turf algae, sediments can exacerbate the ability of the turf algae to attack corals and weaken the ability of corals to resist algal invasion. Our data on the interactions between coral and algae were collected during a snapshot in time, and long-term field surveys and experiments need to be conducted to further understand the impact of sediments, their release of nutrients and housing of pathogens on coral-algal interactions as well as to determine the underlying mechanisms.

\section{Acknowledgements}


371 Hainian Yu from the University of Queensland for English writing improvement. And many

372 thanks to the captain Haichun Su. Finally, we would like to acknowledge, with great gratitude,

373 the patience and support of two anonymous expert reviewers, whose detailed, constructive and

374 highly encouraging feedback have helped us significantly in our refinement of this manuscript. 
References

376

377

378

379

380

381

Abramoff MD, Magalhaes PJ, Ram SJ. 2004. Image processing with ImageJ. Biophotonics International 11:36-42.

Barott KL, Rohwer FL. 2012. Unseen players shape benthic competition on coral reefs. Trends in Microbiology 20:621-628 DOI 10.1016/j.tim.2012.08.004.

Barott K, Smith J, Dinsdale E, Hatay M, Sandin S, Rohwer F. 2009. Hyperspectral and physiological analyses of coral-algal interactions. PLoS One 4:e8043

DOI 10.1371/journal.pone.0008043.

Barott KL, Williams GJ, Vermeij MJ, Harris J, Smith JE, Rohwer FL, Sandin SA. 2012. Natural history of coral-algae competition across a gradient of human activity in the Line Islands. Marine Ecology Progress Series 460:1-12 DOI 10.3354/meps09874.

Bellwood DR, Fulton CJ. 2008. Sediment-mediated suppression of herbivory on coral reefs: decreasing resilience to rising sea levels and climate change? Limnology and Oceanography 53:2695-2701 DOI 10.4319/1o.2008.53.6.2695.

Bellwood DR, Hughes TP, Folke C, Nyström M. 2004. Confronting the coral reef crisis. Nature 429:827-833 DOI 10.1038/nature02691.

Birrell CL, McCook LJ, Willis BL. 2005. Effects of algal turfs and sediment on coral settlement. Marine Pollution Bulletin 51:408-414 DOI 10.1016/j.marpolbul.2004.10.022. 
393

394

395

Birrell CL, McCook LJ, Willis BL, Diaz-Pulido GA. 2008. Effects of benthic algae on the replenishment of corals and the implications for the resilience of coral reefs. Oceanography and Marine Biology 46:25-63 DOI 10.1201/9781420065756.ch2.

Bonaldo RM, Hay ME. 2014. Seaweed-coral interactions: variance in seaweed allelopathy, coral susceptibility, and potential effects on coral resilience. PLoS One 9:e85786

DOI 10.1371/journal.pone.0085786.

Brown K T, Bender-Champ D, Bryant D E P, Dove S, Hoegh-Guldberg O. 2017. Human activities influence benthic community structure and the composition of the coral-algal interactions in the central Maldives. Journal of Experimental Marine Biology and Ecology 497: 33-40 DOI 10.1016/j.jembe.2017.09.006.

Cetz-Navarro NP, Espinoza-Avalos J, Hernández-Arana HA, Carricart-Ganivet JP. 2013. Biological responses of the coral Montastraea annularis to the removal of filamentous turf algae. PLoS One 8:e54810 DOI 10.1371/journal.pone.0054810.

Chen G, Zhao MX, Bin L, Zhang CH, Liang Q. 2016. Ecological situation of coral reefs in the Weizhou Island based on reef check. Tropical Geography 36:66-71 DOI 10.13284/j.cnki.rddl.002807.

Connell SD, Foster MS, Airoldi L. 2014. What are algal turfs? Towards a better description of turfs. Marine Ecology Progress Series 495:299-307 DOI 10.3354/meps10513. 
411 Erftemeijer PLA, Riegl B, Hoeksema BW, Todd PA. 2012. Environmental impacts of dredging 412 and other sediment disturbances on corals: a review. Marine Pollution Bulletin 64:17371765 DOI 10.1016/j.marpolbul.2012.05.008.

414 Ferrari R, Gonzalez-Rivero M, Mumby, PJ. 2012. Size matters in competition between corals and macroalgae. Marine Ecology Progress Series 467:77-88 DOI 10.3354/meps09953.

416 Foster NL, Box SJ, Mumby PJ. 2008. Competitive effects of macroalgae on the fecundity

Friedlander M, Kosov Y, Keret G, Dawes C. 2006. Production of rhizoids by Caulerpa prolifera

Gilmour J. 1999. Experimental investigation into the effects of suspended sediment on fertilisation, larval survival and settlement in a scleractinian coral. Marine Biology 135:451-

Goatley CHR, Bellwood DR. 2011. Sediment suppresses herbivory across a coral reef depth 462 DOI $10.1007 / \mathrm{s} 002270050645$. gradient. Biology Letters 8:1016-1018 DOI 10.1098/rsbl.2012.0770.

Goatley CHR, Bellwood DR. 2013. Ecological consequences of sediment on high-energy coral reefs. PLoS One 8:e77737 DOI 10.1371/journal.pone.0077737. 

indicators of coral reef degradation. Ecology Society 21:29 DOI 10.5751/ES-08334-210129.

430 Gowan JC, Tootell JS, Carpenter, RC. 2014. The effects of water flow and sedimentation on 431 interactions between massive Porites and algal turf. Coral Reefs 33:651-663 DOI 10.1007/s00338-014-1154-1

433 Gregg AK, Hatay M, Haas AF, Robinett NL, Barott K, Vermeij MJA, Marhaver KL, Meirelles 434 P, Thompson F, Rohwer F. 2013. Biological oxygen demand optode analysis of coral reef435 associated microbial communities exposed to algal exudates. PeerJ 1: e107 DOI 10.7717/peerj.107.

437

Haas AF, el-Zibdah M, Wild C. 2010. Seasonal monitoring of coral-algae interactions in fringing reefs of the Gulf of Aqaba, Northern Red Sea. Coral Reefs 29:93-103 DOI 10.1007/s00338-009-0556-y.

Haas AF, Gregg AK, Smith JE, Abieri ML, Hatay M, Rohwer F. 2013. Visualization of oxygen distribution patterns caused by coral and algae. PeerJ 1: e106 DOI 10.7717/peerj.106.

Harrington L, Fabricius K, De'ath G, Negri A. 2008. Recognition and selection of settlement substrata determine post-settlement survival in corals. Ecology 85:3428-3437 DOI 10.1890/04-0298.

Hay ME. 1981. The functional morphology of turf-forming seaweeds: persistence in stressful marine habitats. Ecology 62:739-750 DOI 10.2307/1937742. 
447 Hoegh-Guldberg O, Mumby PJ, Hooten AJ, Steneck RS, Greenfield P, Gomez E, Harvell CD, 448 Sale PF, Edwards AJ, Caldeira K, Knowlton N, Eakin CM, Iglesias-Prieto R, Muthiga N, 449 Bradbury RH, Dubi A, Hatziolos ME. 2007. Coral reefs under rapid climate change and ocean acidification. Science 318:1737-1742 DOI 10.1126/science.1152509.

451

452

Hughes TP. 1994. Catastrophes, phase shifts, and large-scale degradation of a Caribbean coral reef. Science 265:1547-1551 DOI 10.1126/science.265.5178.1547.

Jompa J, McCook LJ. 2003. Coral-algal competition: macroalgae with different properties have different effects on corals. Marine Ecology Progress Series 258:87-95

DOI $10.3354 / \operatorname{meps} 258087$.

Kohler KE, Gill SM. 2006. Coral Point Count with Excel extensions (CPCe): a visual basic program for the determination of coral and substrate coverage using random point count methodology. Computer and Geosciences 32:1259-1269 DOI 10.1016/j.cageo.2005.11.009.

Lirman D. 2001. Competition between macroalgae and corals: effects of herbivore exclusion and increased algal biomass on coral survivorship and growth. Coral Reefs 19:392-399 DOI $10.1007 / \mathrm{s} 003380000125$.

Littler MM, Littler DS, Brooks BL. 2006. Harmful algae on tropical coral reefs: bottom-up eutrophication and top-down herbivory. Harmful algae 5:565-585 
465 Longo GO, Hay ME. 2015. Does seaweed-coral competition make seaweeds more palatable?

$466 \quad$ Coral Reefs 34:87-96 DOI 10.1007/s00338-014-1230-6.

467 McCook LJ. 2001. Competition between corals and algal turfs along a gradient of terrestrial

468 influence in the nearshore central Great Barrier Reef. Coral reefs 19:419-425

469

DOI 10.1007/s003380000119.

470

471

472

473

474

475

476

477

478

479

480

481

482

McCook LJ, Jompa J, Diaz-Pulido G. 2001. Competition between corals and algae on coral reefs: a review of evidence and mechanisms. Coral Reefs 19:400-417

DOI $10.1007 / \mathrm{s} 003380000129$.

Meesters EH, Wesseling I, Bak RPM. 1996. Partial mortality in three species of reef-building corals and the relation with colony morphology. Bulletin of Marine Science 58:838-852.

Negri AP, Webster NS, Hill RT, Heyward1 AJ. 2001. Metamorphosis of broadcast spawning corals in response to bacteria isolated from crustose algae. Marine Ecology Progress Series 223:121-131 DOI 10.3354/meps223121.

Nugues MM, Roberts CM. 2003. Coral mortality and interaction with algae in relation to sedimentation. Coral Reefs 22:507-516 DOI 10.1007/s00338-003-0338-x.

Nugues MM, Bak R. 2006. Differential competitive abilities between Caribbean coral species and a brown alga: a year of experiments and a long-term perspective. Marine Ecology Progress Series 315:75-86 DOI 10.3354/meps315075. 
483 Preskitt LB, Vroom PS, Smith CM. 2004. A rapid ecological assessment (REA) quantitative

484

485

486

487

488

489

490

491

492

493

494

495

496

497

498

499

500 survey method for benthic algae using photoquadrats with scuba. Pacific Science 58:201209 DOI 10.1353/psc.2004.0021.

Purcell SW. 2000. Association of epilithic algae with sediment distribution on a windward reef in the northern Great Barrier Reef, Australia. Bulletin of Marine Science 66:199-214.

Rasher DB, Hay ME. 2010. Chemically rich seaweeds poison corals when not controlled by herbivores. Proceedings of the National Academy of Sciences 107:9683-9688

DOI 10.1073/pnas.0912095107.

Rasher DB, Stout EP, Engel S, Kubanek J, Hay ME. 2011. Macroalgal terpenes function as allelopathic agents against reef corals. Proceedings of the National Academy of Sciences 108:17726-17731 DOI 10.1073/pnas.1108628108.

Roach TNF, Abieri ML, George EE, Knowles B, Naliboff DS, Smurthwaite CA, Kelly LW, Haas AF, Rohwer FL. 2017. Microbial bioenergetics of coral-algal interactions. PeerJ 5: e3423 DOI 10.7717/peerj.3423.

Smith JE, Shaw M, Edwards RA, Obura D, Pantos O, Sala E, Sandin SA, Smriga S, Hatay M, Rohwer FL. 2006. Indirect effects of algae on coral: algae-mediated, microbe-induced coral mortality. Ecology Letters 9:835-845 DOI 10.1111/j.1461-0248.2006.00937.x. 
501

502

503

504

505

506

507

508

509

510

511

512

513

514

515

516

517

518

complex interactions along reef productivity gradients. Proceedings of the Eighth International Coral Reef Symposium 1:695-700.

Sun Y, Lei X, Lian J, Yang J, Wu Y, Huang H. 2018. Ecosystem status and health assessment of Sanya Coral Reef National Nature Reserve. Biodiversity science 26(3):258-265

DOI 10.17520/biods.2017312

Swierts T, Vermeij MJA. 2016. Competitive interactions between corals and turf algae depend on coral colony form. PeerJ 4:e1984 DOI 10.7717/peerj.1984.

Titlyanov EA, Yakovleva IM, Titlyanova TV. 2007. Interaction between benthic algae (Lyngbya bouillonii, Dictyota dichotoma) and scleractinian coral Porites lutea in direct contact. Journal of Experimental Marine Biology and Ecology 342:282-291

DOI 10.1016/j.jembe.2006.11.007.

Vermeij MJA, Sandin SA. 2008. Density-dependent settlement and mortality structure the earliest life phases of a coral population. Ecology 89:1994-2004 DOI 10.1890/07-1296.1.

Vermeij MJA, Smith JE, Smith CM, Vega Thurber R, Sandin SA. 2009. Survival and settlement success of coral planulae: independent and synergistic effects of macroalgae and microbes. Coral reefs 159:325-336 DOI 10.1007/s00442-008-1223-7.

Vermeij MJA, van Moorselaar I, Engelhard S, Hörnlein C, Vonk SM, Visser PM. 2010. The effects of nutrient enrichment and herbivore abundance on the ability of turf algae to 
520

Vieira C, Engelen AH, Guentas L, Aires T, Houlbreque F, Gaubert J, Serrão EA, De Clerck O, Payri CE. 2016. Species specificity of bacteria associated to the brown seaweeds Lobophora (Dictyotales, Phaeophyceae) and their potential for induction of rapid coral bleaching in Acropora muricata. Frontiers Microbiology 7:316 DOI 10.3389/fmicb.2016.00316.

Wang WH, Yu KF, Wang YH. 2016. A review on the research of coral reefs in the Weizhou Islan, Beibu Gulf. Tropical Geography 36:72-79 DOI 10.13284/j.cnki.rddl.002806.

Wang X. 2009. Research of the relationship between the deposit of suspended and the growth of coral reef in Weizhou Island, Beibu Bay. M. Sc. Thesis, Guangxi University.

Wangpraseurt D, Weber M, Røy H, Polerecky L, de Beer D, Suharsono, Nugues MM. 2012. In situ oxygen dynamics in coral-algal interactions. PLoS One 7:e31192

DOI 10.1371/journal.pone.0031192.

Wei CL, Gao JS, Cao X F, Ya HZ, Chen B, Shi MC. 2017. Observational analysis of the surface current characteristics and mechanisms off the southern coast of Weizhou Island, Guangxi. Periodical of Ocean University of China 47(4):7-13 DOI 10.16441/j.cnki.hdxb.20160137.

Wild C, Jantzen C, Kremb SG. 2014. Turf algae-mediated coral damage in coastal reefs of Belize, Central America. PeerJ 2:e571 DOI 10.7717/peerj.571. 
537 green macroalga Caulerpa cupressoides. Limnology and Oceanography 29 (2), 374-379.

$538 \quad$ DOI 10.4319/1o.1984.29.2.0374.

539 Wilson S, Bellwood DR. 1997. Cryptic dietary components of territorial damselfishes

540 (Pomacentridae, Labroidei). Marine Ecology Progress Series 153:299-310

$541 \quad$ DOI $10.3354 /$ meps 153299.

542 Yu KF. 2012. Coral reefs in the South China Sea: their response to and records on past

543 environmental changes. Science China Earth Sciences, 55(8):1217-1229

544 DOI 10.1007/s11430-012-4449-5. 


\section{Figure 1}

Maps of Weizhou Island, Beibu Gulf, and study sites.

(A) Map of Weizhou Island in the Beibu Gulf of the South China Sea. (B) The eight transects are marked with red dots; the table inset shows the cover of biological and non-biological substrates and the number of surveyed coral colonies at each site. 


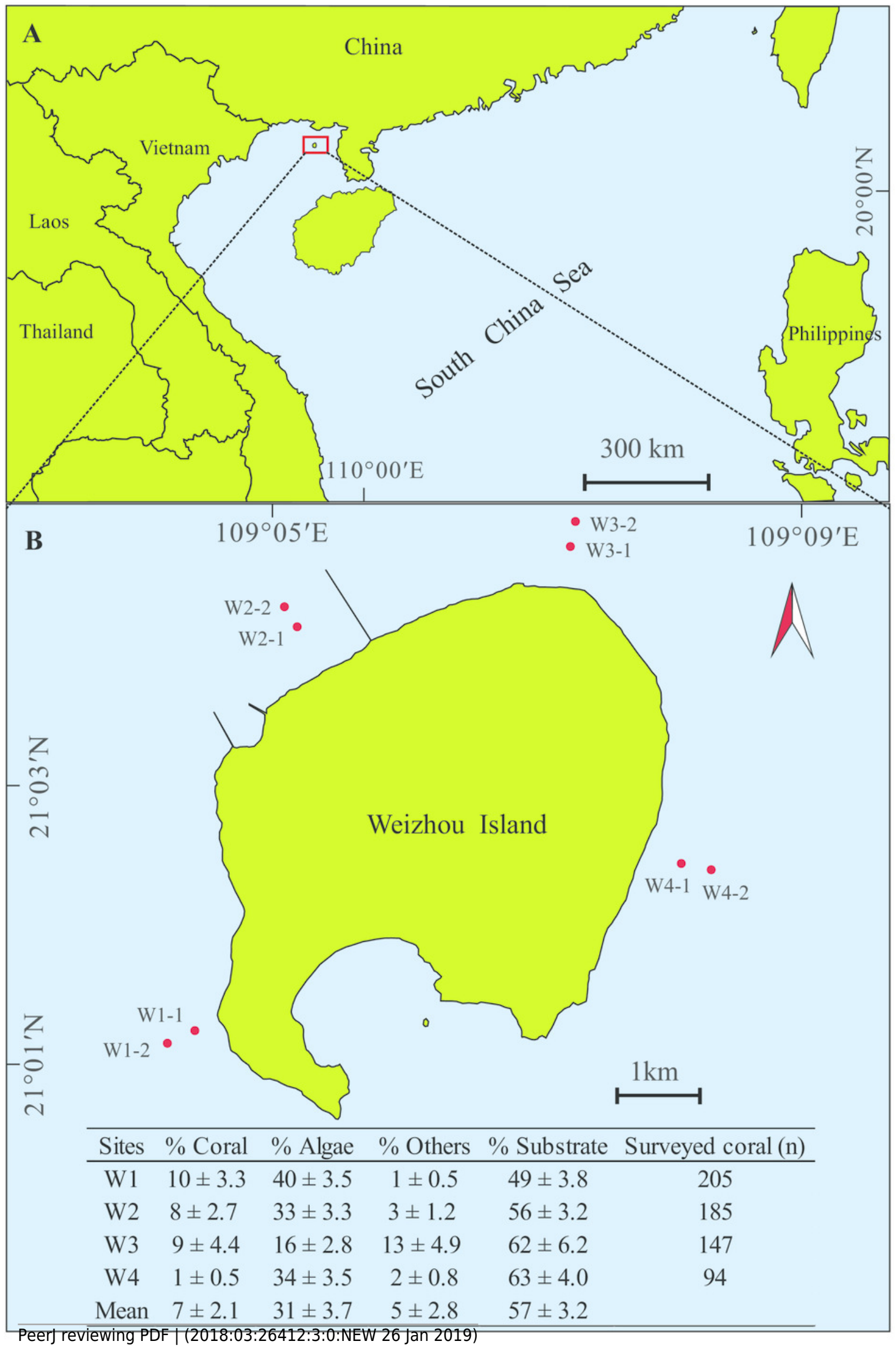




\section{Figure 2}

Examples of coral-algal interactions and the effects of sediments bound within turf algae.

(A, B) Typical interaction interfaces of the Favites and Porites genera and algae (turf algae and $L$. variegata). (C) Porites colony surrounded by turf algae with massive sediments trapped in sparse turf algae, a widespread phenomenon at surveyed reef; (D) the same Porites colony showing bleached tissue after sediments were removed using a burst of air. (E) An example of the interaction outcomes between the genus Favites and turf algae. 'Turf $+S$ ' indicates turf algae with sediment; 'Turf - $S$ ' indicates turf algae without sediment. Photo credit: Zhiheng Liao. 

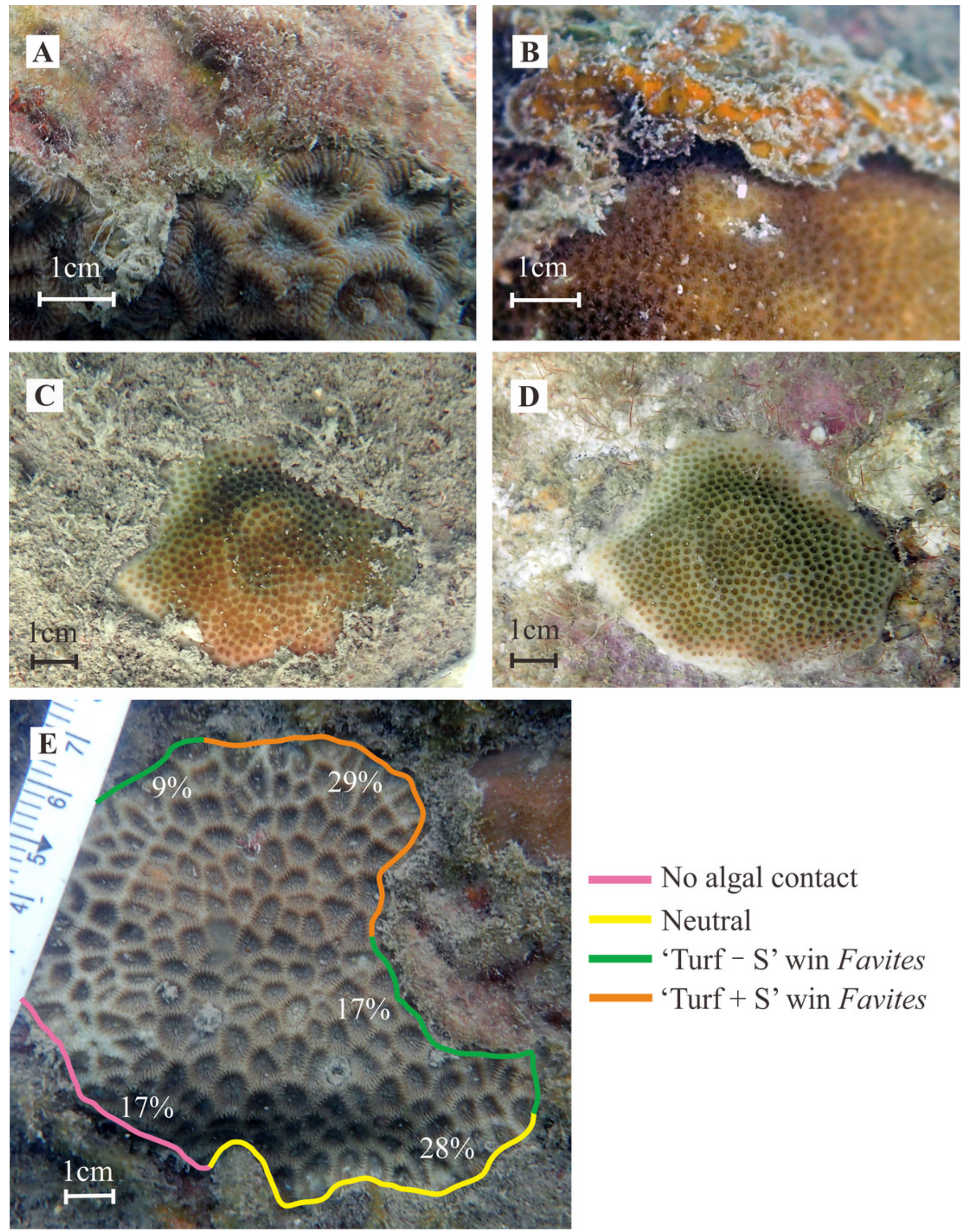


\section{Figure 3}

Percentage of coral and algae cover on the coral reef of Weizhou Island.

The bar within each box represents the median; the two bars above and below each box represent the upper and lower $25 \%$ quartiles, respectively; the whiskers represent the minimum and maximum values; ' $\boldsymbol{\theta}$ ' represents the mean value; ' $O$ ' indicates the data $>$ the 1.5 interquartile range; ' $\triangle$ ' indicates the data $>$ the 3.0 interquartile range. CCA: crustose coralline algae. 


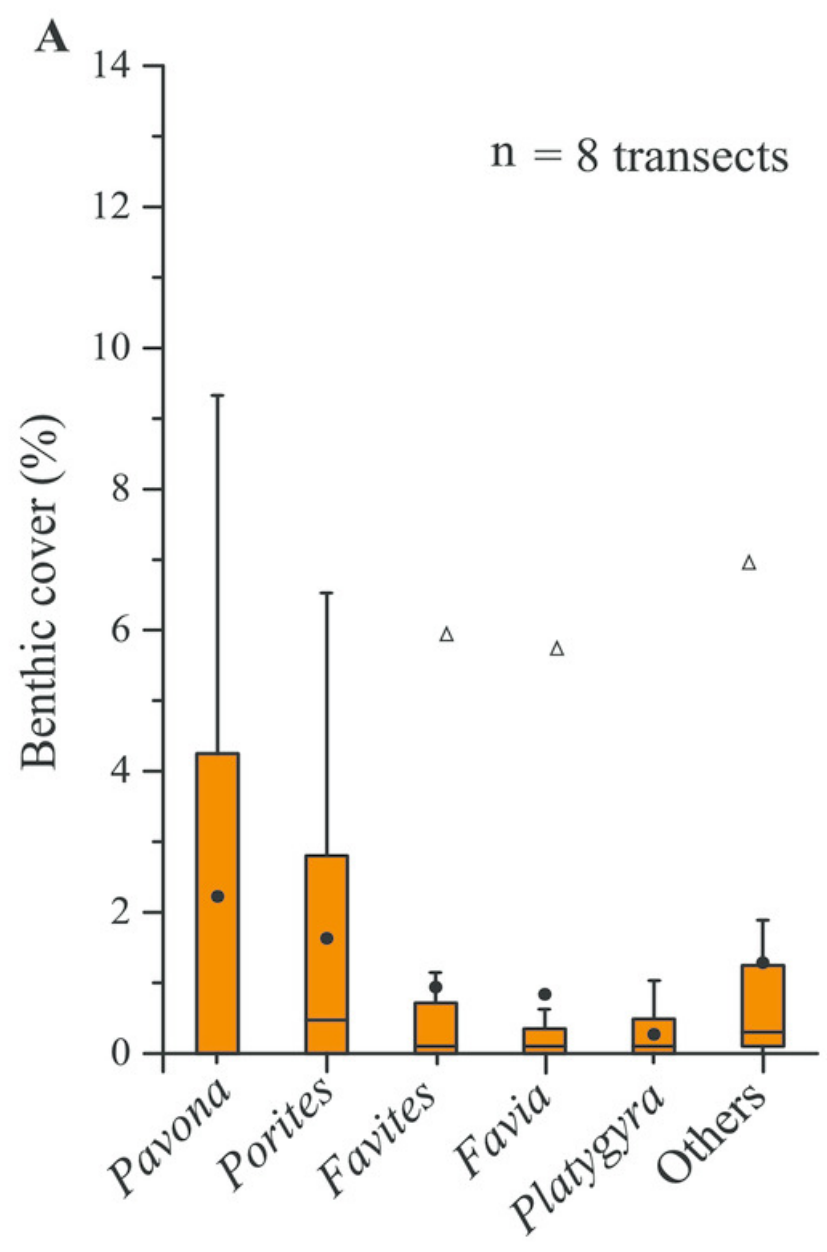

B

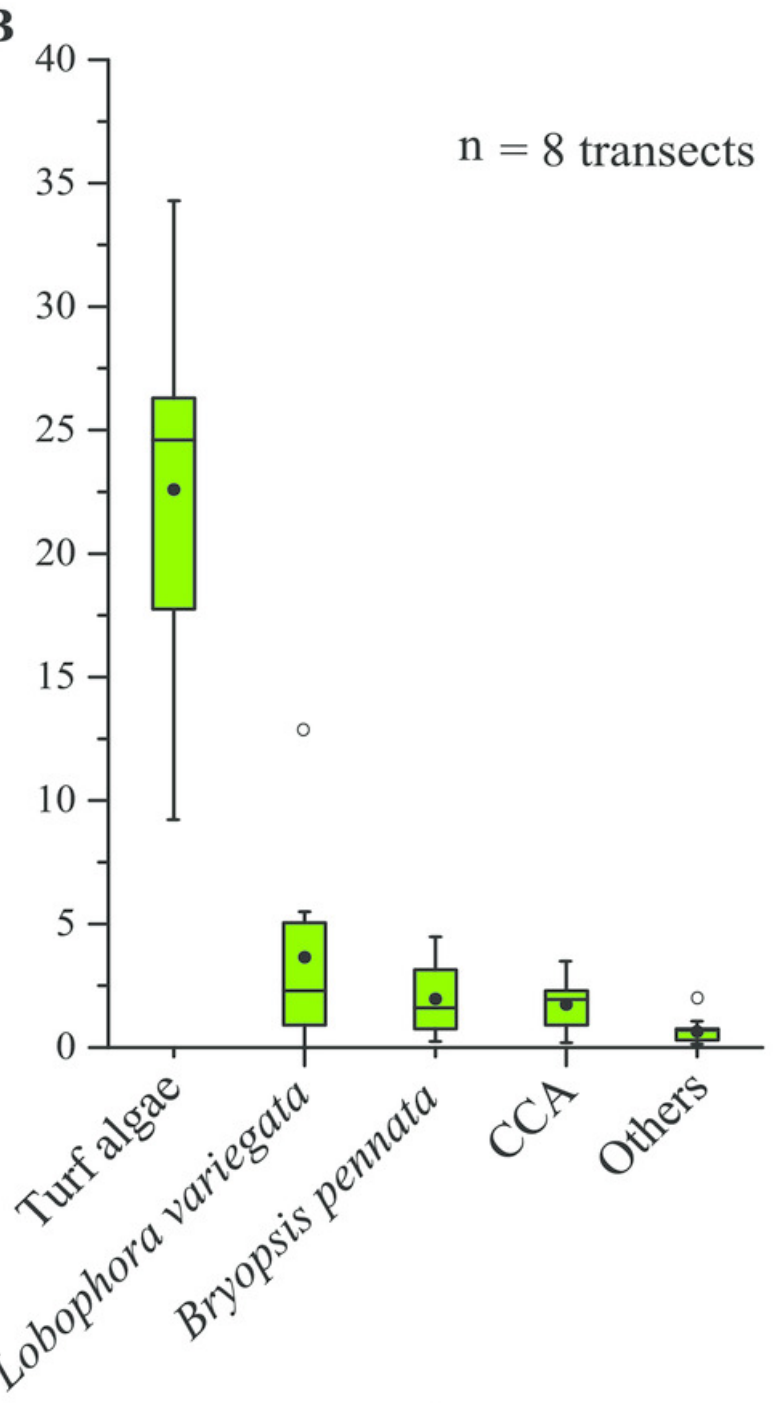

Coral genera

Algal taxa 


\section{Figure 4}

Competitive outcomes between corals and turf algae.

(A) Proportions of coral edges in contact with turf algae. (B) Competitive outcomes between coral and turf algae, where green (algal overgrowth) and purple (coral bleaching) indicate the proportions of algal wins, yellow indicates the proportions of neutral outcomes, and orange indicates the proportions of coral wins. The numbers indicate the number of coral colonies included in the analyses. Similar letters (uppercase or lowercase) above each set of bars indicate significant differences (assessed by a Kruskal-Wallis test) in post-hoc comparisons for a specific competitive outcome among coral genera (SNK test, $p<0.05$ ). 


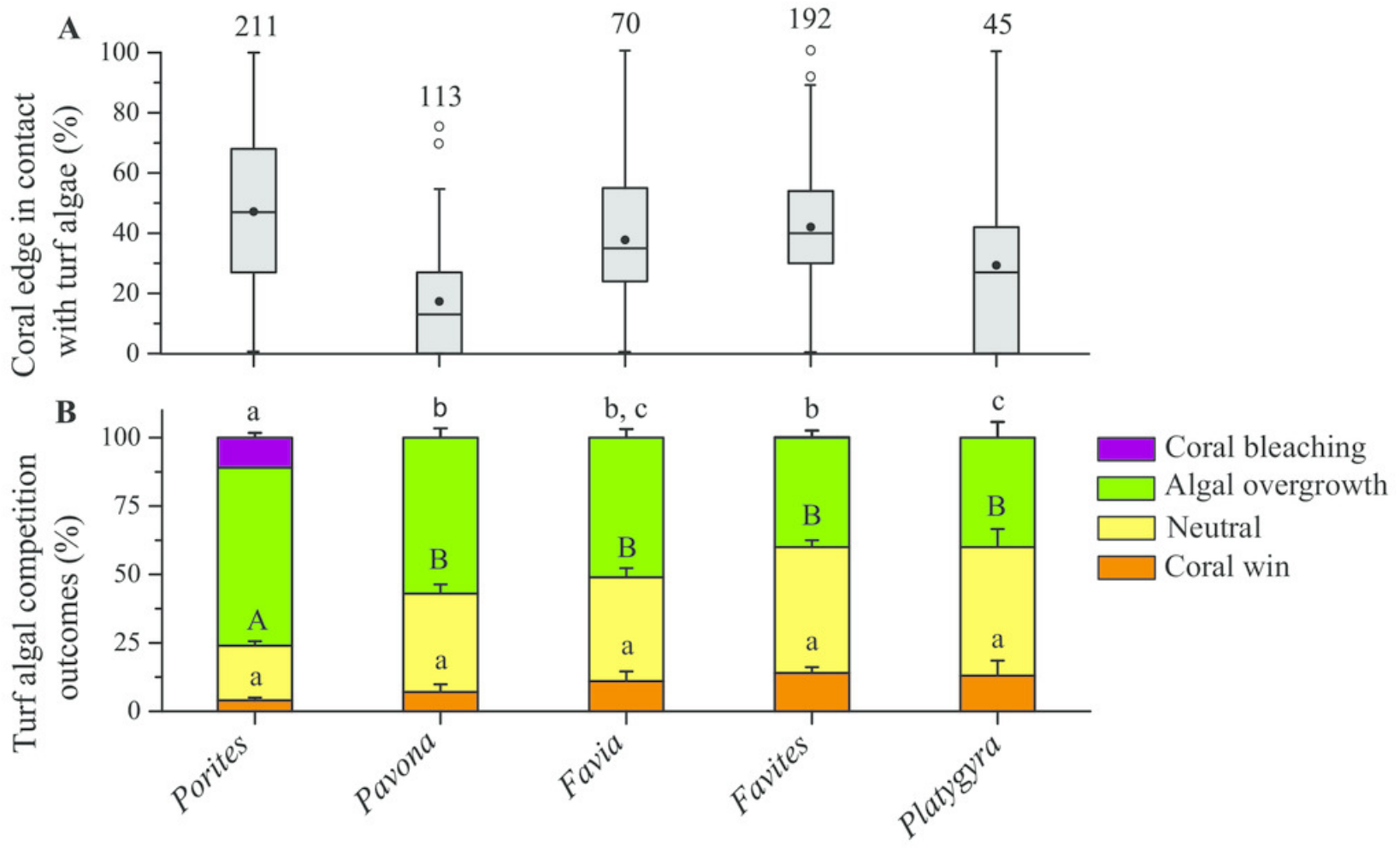

Coral genera 


\section{Figure 5}

Competitive outcomes between corals and macroalgae.

(A) Proportions of coral edges in contact with macroalgae. (B) Competitive outcomes

between corals and macroalgae, where green (algal overgrowth) and purple (coral bleaching) indicate the proportions of algal wins, yellow indicates the proportions of neutral outcomes, and orange indicates the proportions of coral wins. The numbers indicate the number of coral colonies included in the analyses. Similar letters (uppercase or lowercase) above each set of bars indicate significant differences (assessed by a Kruskal-Wallis test) in post-hoc comparisons for a specific competitive outcome among coral genera (SNK test, $p<0.05$ ). 


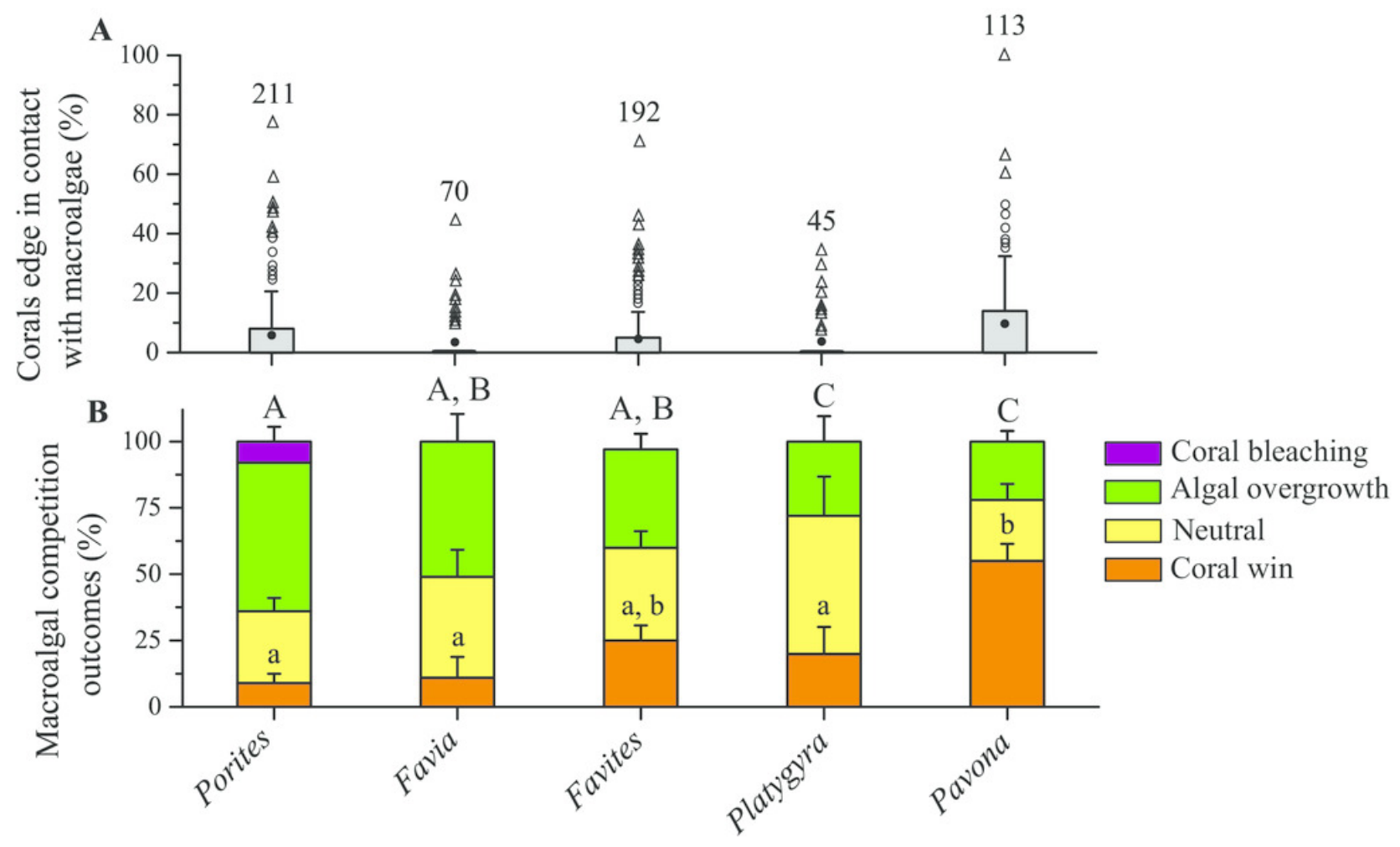

Coral genera 


\section{Figure 6}

Proportions of algal wins observed along edges of different coral genera.

(A) Proportions of turf algal wins on coral genera, with turf algae grouped into 'Turf $+\mathrm{S}$ ' (turf algae with sediments) and 'Turf - S' (turf algae without sediments). (B) Proportions of macroalgal wins on coral genera. The numbers indicate the number of coral colonies included in the analyses. Similar letters (uppercase or lowercase) indicate significant differences (assessed by a two-way ANOVA) in post-hoc comparisons for proportions of algal wins among coral genera (SNK test, $p<0.05$ ). 


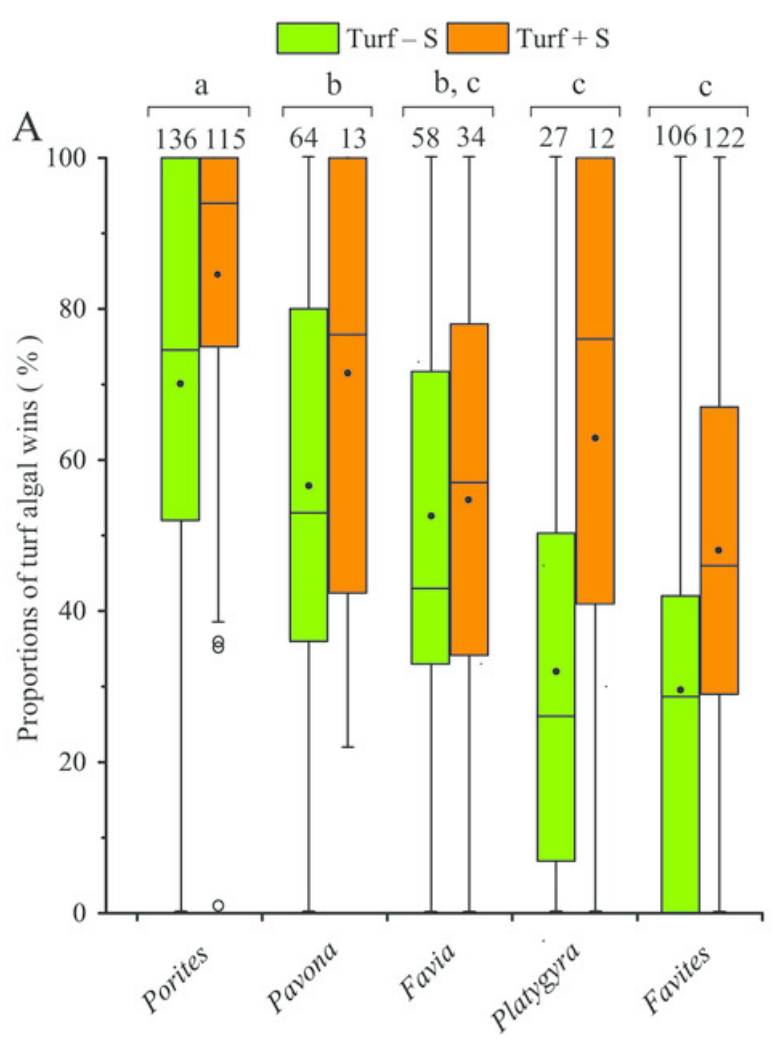

Coral genera

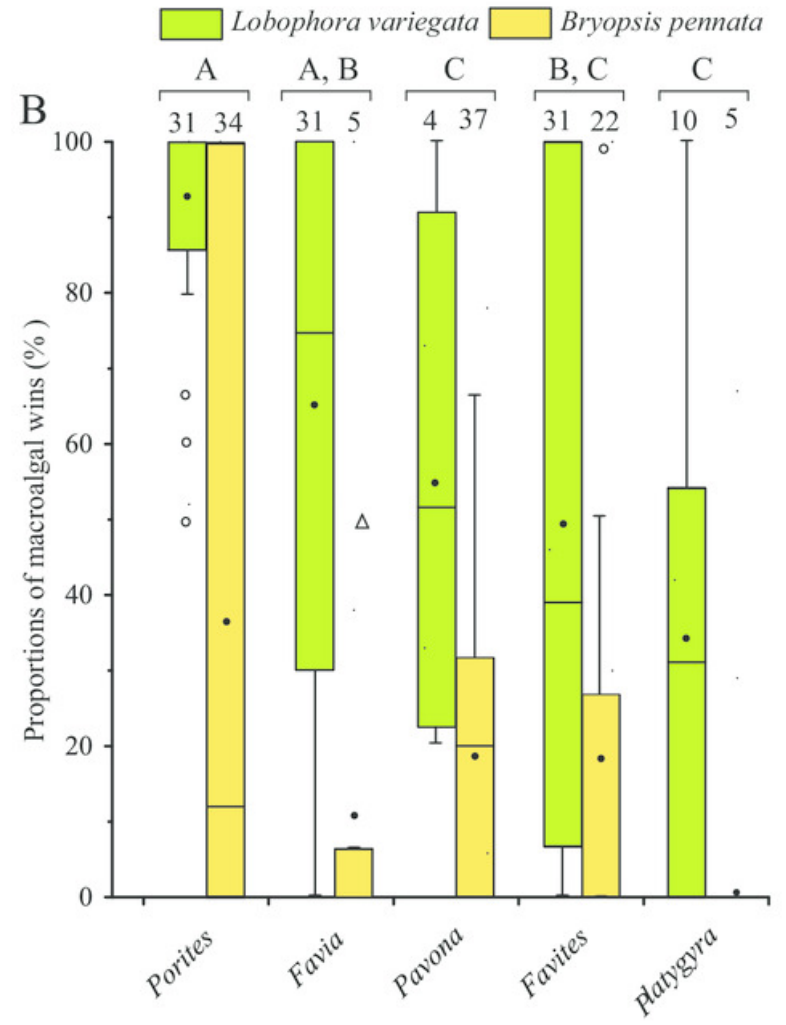

Coral genera 


\section{Figure 7}

Proportions of turf algal wins observed along massive and encrusting coral edges.

Measured interaction groups were massive corals vs. 'Turf - $S$ ', massive corals vs. 'Turf $+\mathrm{S}$ ', encrusting corals vs. 'Turf $-\mathrm{S}$ ', and encrusting corals vs. 'Turf $+\mathrm{S}$ '. 'Turf $+\mathrm{S}$ ' indicates turf algae with sediments and 'Turf - $S$ ' indicates turf algae without sediments. The numbers indicate the number of coral colonies included in the analyses. Similar letters (uppercase or lowercase) indicate significant differences (assessed by a two-way ANOVA) in post-hoc comparisons for proportions of algal wins among interaction groups (SNK test, $p<0.05$ ). 


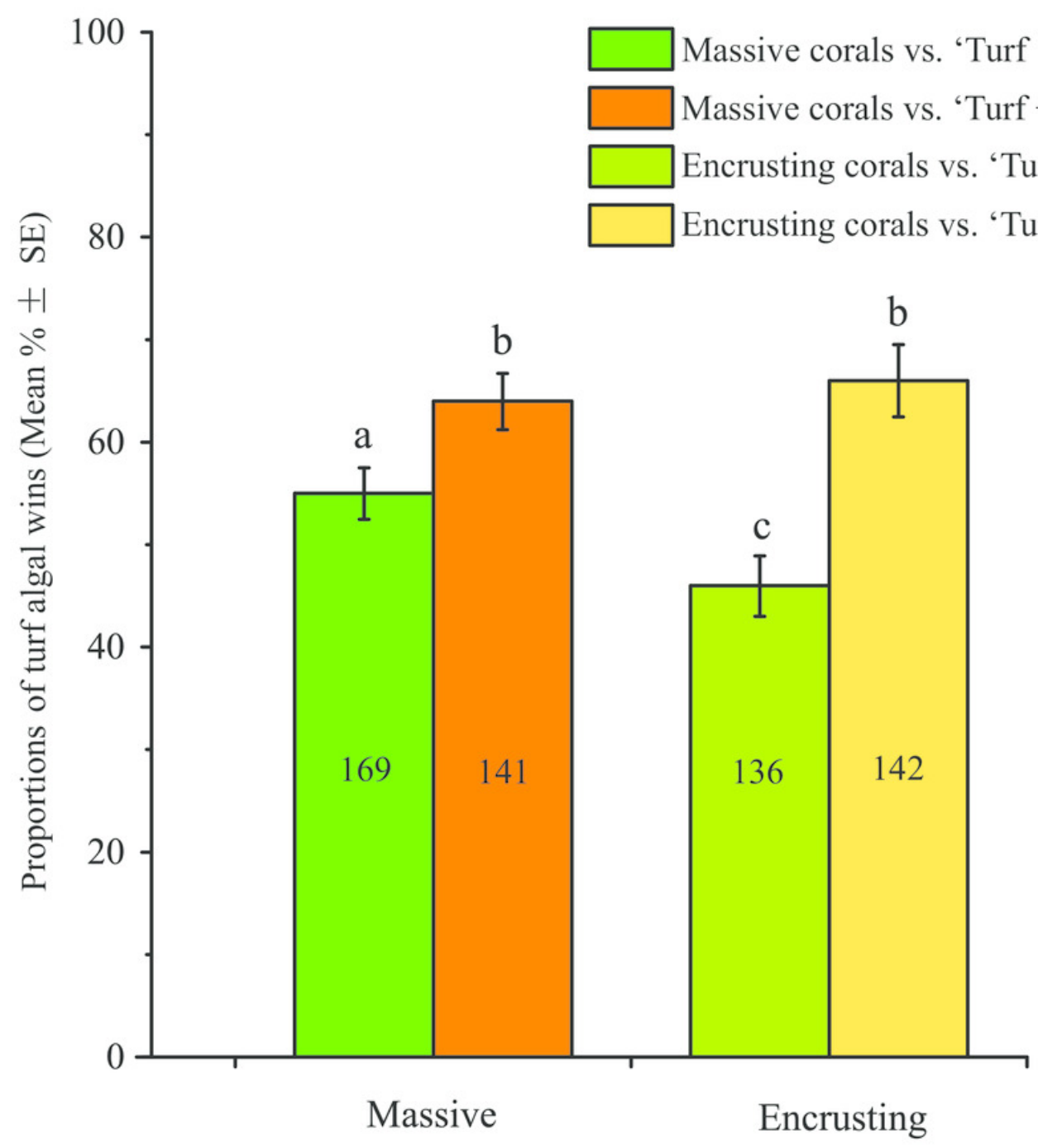

Interaction groups 


\section{Table $\mathbf{1}$ (on next page)}

Frequency of coral-algal contact, and composition and proportion of algae along the coral edges.

Turf algae were divided into 'Turf $+\mathrm{S}$ ' (turf algae with sediments) and 'Turf - $\mathrm{S}$ ' (turf algae without sediments). 


\begin{tabular}{|c|c|c|c|c|c|c|c|}
\hline \multirow{2}{*}{ Genus } & \multirow{2}{*}{$\begin{array}{l}\text { Surveyed } \\
\text { colonies (n) }\end{array}$} & \multirow{2}{*}{$\begin{array}{l}\text { Polyp size } \\
(\mathrm{mm})\end{array}$} & \multirow{2}{*}{$\begin{array}{l}\% \text { Colonies } \\
\text { in contact } \\
\text { with algae }\end{array}$} & \multirow{2}{*}{$\begin{array}{l}\% \text { No } \\
\text { algal } \\
\text { contact }\end{array}$} & \multicolumn{2}{|c|}{$\%$ Turf algal contact } & \multirow{2}{*}{$\begin{array}{l}\% \text { Macroalgal } \\
\text { contact }\end{array}$} \\
\hline & & & & & Turf - S & Turf $+\mathrm{S}$ & \\
\hline Porites & 211 & $2<$ & $86 \pm 2.4$ & $47 \pm 1.9$ & $24 \pm 1.7$ & $23 \pm 1.9$ & $6 \pm 0.8$ \\
\hline Favites & 192 & $>5$ & $80 \pm 5.5$ & $53 \pm 1.5$ & $17 \pm 1.5$ & $25 \pm 1.8$ & $5 \pm 0.7$ \\
\hline Favia & 70 & $>5$ & $85 \pm 2.7$ & $59 \pm 2.8$ & $18 \pm 2.5$ & $20 \pm 3.1$ & $3 \pm 0.9$ \\
\hline Platygyra & 45 & $>5$ & $64 \pm 7.8$ & $67 \pm 4.1$ & $19 \pm 3.3$ & $10 \pm 3.2$ & $4 \pm 1.2$ \\
\hline Pavona & 113 & $2<$ & $61 \pm 3.1$ & $73 \pm 2.2$ & $15 \pm 1.5$ & $3 \pm 0.9$ & $10 \pm 1.8$ \\
\hline Mean value & & & & $56 \pm 1.0$ & $19 \pm 0.9$ & $19 \pm 1.0$ & $6 \pm 0.5$ \\
\hline
\end{tabular}




\section{Table 2 (on next page)}

Results of the two-way ANOVA test for the effects of coral genera and algal types on the proportions of algal contacts along coral edges. 


\begin{tabular}{lcccc}
\hline Source of variation & df & MS & F & $p$ \\
\hline Proportion of algal contact & & & & \\
Coral genus & 4 & 0.47 & 11.99 & $<0.0001$ \\
Algal type & 2 & 2.18 & 55.22 & $<0.0001$ \\
Coral genus $\times$ Algal type & 8 & 0.45 & 11.36 & $<0.0001$ \\
\hline
\end{tabular}

1 